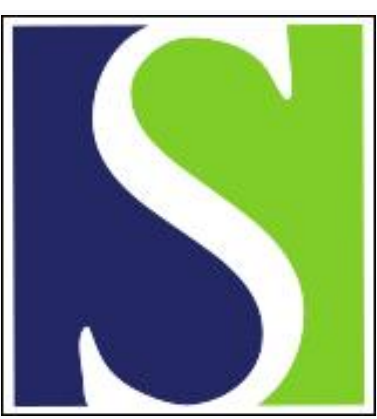

Scand J Work Environ Health 2008;34(4):267-277

https://doi.org/10.5271/sjweh.1243

Published online: 01 Sep 2008, Issue date: Aug 2008

Exposure to environmental tobacco smoke and health effects among hospitality workers in Sweden-before and after the implementation of a smoke-free law

by Larsson M, Boëthius G, Axelsson S, Montgomery SM

Affiliation: The Department of Respiratory Medicine, Örebro University Hospital, SE-70185 Örebro, Sweden. matz.larsson@orebroll.se

Refers to the following text of the Journal: 2005;31(1):75-81

Key terms: air; cotinine; environmental tobacco smoke; exposure; gambling; health effect; hospitality venue; hospitality worker; legislation; nicotine; nicotine in air; passive smoking; smoke-free law; spirometry; Sweden; symptom

This article in PubMed: www.ncbi.nlm.nih.gov/pubmed/18815714 


\title{
Exposure to environmental tobacco smoke and health effects among hospitality workers in Sweden-before and after the implementation of a smoke-free law
}

\author{
by Matz Larsson, MD, ${ }^{1}$ Göran Boëthius, MD, ${ }^{2}$ Sara Axelsson, MSc, ${ }^{3}$ Scott M Montgomery, PhD ${ }^{4}$
}

\begin{abstract}
Larsson M, Boëthius G, Axelsson S, Montgomery SM. Exposure to environmental tobacco smoke and health effects among hospitality workers in Sweden-before and after the implementation of a smoke-free law. Scand $J$ Work Environ Health 2008; 34(4):267-277.
\end{abstract}

\begin{abstract}
Objectives This study attempted to identify changes in exposure to environmental tobacco smoke, as well as symptoms and attitudes among hospitality workers after the introduction of extended smoke-free workplace legislation.

Methods A total of 37 volunteers working in bingo halls and casinos (gaming workers) and 54 bars and restaurant employees (other workers) in nine Swedish communities participated in the study. Altogether 71 of 91 persons (14 daily smokers and 57 nonsmokers) participated in both the preban baseline survey and the follow-up 12 months after the ban. Exposure to environmental tobacco smoke, smoking habits, respiratory and sensory symptoms, and attitudes towards the ban were recorded, and spirometry was carried out.

Results The frequency of reported respiratory and sensory symptoms was approximately halved among the nonsmokers in both occupational groups after the introduction of the ban. Initially $87 \%$ had exposure to environmental tobacco smoke that was over the nicotine cut-off level chosen to identify possible health risk $(<0.5$ $\mu \mathrm{g} / \mathrm{m}^{3}$ ), while, after the ban, it was only $22 \%$, a relative risk of 0.25 (95\% confidence interval $0.15-0.41$ ). The risk decreased in both occupational groups, but gaming workers experienced the highest preban exposure levels. Attitudes towards the legislation were largely positive, particularly after the ban. However, there was no notable change in lung function, and there was no notable reduction in the number of cigarettes consumed by smokers. Conclusions The introduction of smoke-free legislation was associated with a substantial reduction in respiratory and sensory symptoms, as well as reduced exposure to environmental tobacco smoke at work, particularly among gaming workers.
\end{abstract}

Key terms cotinine; gambling; hospitality venue; legislation; nicotine in air; passive smoking; spirometry; symptom.

Several European countries, including Ireland, Norway, Italy, and Spain, have introduced a policy to eliminate smoking from workplaces and public buildings, including bars and restaurants (1-3). Sweden extended its smoke-free workplace policy to include hospitality workers, such as bar and restaurant personal, on 1 June 2005. Workers in the hospitality sector may experience particularly high levels of exposure to environmental tobacco smoke $(4,5)$, with exposure to airborne nicotine concentrations of up to 18.5 times higher than in offices or domestic residences (6). It is therefore important to assess the effects of the smoke-free legislation on workers in this sector. Previous research has mainly investigated bar workers (2, 7-9), while this study also includes casino and bingo hall workers, who are seldom examined in this context (10).

The rate of respiratory symptoms among hospitality workers is notably elevated due to exposure to environmental tobacco smoke (11). As a reduction in exposure to environmental tobacco smoke may reduce the

1 The Department of Respiratory Medicine, Örebro University Hospital, Örebro, Sweden.

2 Tobacco Control Unit, Östersund Hospital, Östersund, Sweden.

3 Department of Occupational and Environmental Medicine. Örebro University Hospital, Örebro, Sweden.

4 Kliniskt Forskningscentrum, Örebro University Hospital, Örebro, Sweden; The Clinical Epidemiology Unit, Department of Medicine, Karolinska Hospital, Karolinska Institutet, Stockholm, Sweden; and The Department of Primary Care and Social Medicine, Charing Cross Hospital, Imperial College, London, United Kingdom.

Correspondence to: Dr Matz Larsson, The Department of Respiratory Medicine, Örebro University Hospital, SE-70185 Örebro, Sweden. [E-mail: matz.larsson@orebroll.se] 
frequency of respiratory and sensory symptoms among bar workers (2, 7-9), a similar benefit may be observed among Swedish hospitality workers. In the context of examining the change in the rate of such symptoms, it is important to establish whether the introduction of the legislation is accompanied by a real reduction in environmental tobacco smoke. In Norway, similar legislation (12) was associated with a reduction in particulate levels in bars and restaurants from an average of $262 \mu \mathrm{g} / \mathrm{m}^{3}$ to $77 \mu \mathrm{g} / \mathrm{m}^{3}$, a $70 \%$ reduction. Mulcahy et al (13) measured changes in airborne nicotine levels as a result of the Irish smoke-free legislation, and they found a reduction of approximately $83 \%$. Attitudes towards the legislation may also be important in determining its long-term success.

In addition to associations with acute respiratory and sensory symptoms, it is possible that the reduced exposure to environmental tobacco smoke that is associated with legislation may have more profound health effects. Some studies indicate that a reduction in exposure to environmental tobacco smoke can result in modest improvements in respiratory function $(2,7,9)$. There is

Table 1. Characteristics of the participants.

\begin{tabular}{|c|c|c|c|c|}
\hline \multirow[t]{2}{*}{ Characteristic } & \multicolumn{2}{|c|}{$\operatorname{Preban}^{\mathrm{a}}(\mathrm{N}=91)$} & \multicolumn{2}{|c|}{12 months postban ${ }^{b}$} \\
\hline & $\mathrm{N}$ & $\%$ & $\mathrm{~N}$ & $\%$ \\
\hline Female & 64 & 70 & 50 & 70 \\
\hline Male & 27 & 30 & 21 & 30 \\
\hline Smoker ${ }^{c}$ & 24 & 26 & 14 & 20 \\
\hline Nonsmoker & 67 & 74 & 57 & 80 \\
\hline Daily snuff use & 3 & 3 & 1 & 1.4 \\
\hline Irregular snuff use & 3 & 3 & 2 & 2.8 \\
\hline \multicolumn{5}{|l|}{ Profession } \\
\hline Gaming worker & 37 & 41 & 27 & 38 \\
\hline In bingo hall & 22 & 24 & 14 & 20 \\
\hline In casino & 15 & 16 & 13 & 18 \\
\hline Other worker & 54 & 59 & 44 & 62 \\
\hline Waiter or waitress & 28 & 31 & 25 & 35 \\
\hline Bar staff & 14 & 15 & 11 & 15 \\
\hline Other function ${ }^{d}$ & 12 & 13 & 8 & 11 \\
\hline \multicolumn{5}{|l|}{ Participation rate ${ }^{e}$} \\
\hline Completed the questionnaire & 91 & 100 & 71 & 100 \\
\hline Completed the diary & 83 & 91 & 61 & 86 \\
\hline Spirometry & 90 & 99 & 67 & 94 \\
\hline Nicotine in the air & 83 & 91 & 60 & 84 \\
\hline Urine cotinine & 72 & 79 & 56 & 79 \\
\hline
\end{tabular}

a Mean 33.3 years and range 18-65 years for age; mean 33 hours and range $0-65$ hours for working the week before.

${ }^{\mathrm{b}}$ Mean 36.5 years and range 18-65 years for age; mean 33 hours and range 0-78 hours for working the week before.

${ }^{c}$ All of the smokers were daily smokers.

d For example, owner, discjockey, both bar worker and waiter.

${ }^{\text {e }}$ Altogether 43 participants filled out a questionnaire, kept a diary, and underwent spirometry, nicotine sampling, and urine cotinine sampling at both times. some evidence that exposure to environmental tobacco smoke is linked with an increased risk for a variety of diseases, including coronary artery disease $(14,15)$, obstructive lung disease (16-18), stroke (19), and lung cancer $(20,21)$.

This study evaluated the influence of the smoke-free legislation among a sample of hospitality workers in Sweden by examining the change in the rate of respiratory and sensory symptoms among the same persons before and 12 months after its introduction. As part of the assessment of compliance, the levels of environmental tobacco smoke were monitored at the workplaces involved in the study. As airborne nicotine concentrations may be important in determining mutagenicity $(10,22)$, we set cut off-levels that have been estimated as risk relevant to a potent bladder carcinogen , 4-aminobiphenyl (4-ABP) (22), as a general marker of potential disease risk. Spirometry was used to assess any change in lung function, and questionnaires recorded information on tobacco use and exposure to environmental tobacco smoke at work and during leisure time, as well as attitudes towards the legislation.

\section{Study population and methods}

The sample was broadly representative of Sweden, and staff were enrolled who were working in bars, restaurants, and bingo halls in nine communities throughout Sweden. A baseline survey was performed 1 month before the ban (April-May 2005), and data were again collected 12 months later (April-May 2006). Both nonsmokers and daily smokers were included. The research ethics committee of the Faculty of Medicine, Umeå, Sweden, approved the study.

\section{Participant selection}

The characteristics of the participants are described in table 1. The volunteers were recruited through two routes. A trade union (Hotell och Restauranganställdas Förbund) forwarded information to members about the study, asking them to contact the research team if they were interested in participating. A restaurant and hotel chain (Scandic) also helped to recruit volunteers from among its staff.

The inclusion criteria included working as a waiter, bar staff, or croupier in a restaurant, bar, nightclub, casino, or bingo hall, where a smoke-free policy was not implemented before the legislation came into force.

Smokers and nonsmokers were included, but occasional smoking was an exclusion criterion (smoking in the last 12 months but not daily), as high variation may confound associations with symptom frequency. Snuff 
use was permitted. Other exclusion criteria were an already smoke-free workplace prior to implementation of the law and a work period shorter than three consecutive days per week. We accepted all eligible volunteers able to participate before the introduction of the ban. Altogether 91 persons were investigated at the start of the study, and $64(70 \%)$ of these were women. A total of 71 (79\%) persons participated at the 12-month followup. At the follow-up, at least two attempts were made to contact the earlier participants. Of those participating at both times, 44 of the 67 nonsmokers and 10 of the 14 smokers provided air samples for nicotine on both occasions.

\section{Data collection}

Institutions, predominantly pulmonary clinics, were contacted by mail or telephone, and those willing to participate were involved as data collection centers. They were situated throughout Sweden, including in its seven largest communities (with the number of participants investigated) as follows: 21 in Stockholm, 19 in Göteborg, 6 in Malmö, 5 in Uppsala, 13 in Västerås, 5 in Linköping, 6 in Örebro, 7 in Östersund, and 9 in Skövde. The participants visited their local participating clinic to complete the questionnaire and diary and undergo spirometry, both before and after the introduction of the legislation. Nicotine samplers and test tubes for urine samples were also issued at these times. It was planned that spirometric data would be collected at the end of the workday, but, due to irregular shift times, the collection at this time was only possible for approximately $50 \%$ of the participants, and the remaining data were collected the following day.

\section{Screening of unreported tobacco product use by urine cotinine}

Samples of urine, obtained at the end of a workshift, were immediately frozen and sent to the laboratory, where cotinine assays were performed using liquid extraction-gas chromatography-mass spectrometry (23). Data on smoking and wet snuff use, as well as nicotine replacement therapy, were collected from the questionnaires. The time and duration of workshifts and the time of the collection of the urine samples were also recorded. Cut-off values for cotinine levels distinguishing smokers from nonsmokers vary in the literature; a national survey of the United States population used $15 \mathrm{ng} / \mathrm{ml}(85.2 \mathrm{nmol} / \mathrm{l})$ of serum cotinine as the cut-off (24). Heavy exposure to environmental tobacco smoke may produce serum cotinine concentrations as high as $31.3 \mathrm{ng} / \mathrm{ml}(25,26)$. The corresponding urinary cotinine value is approximately 6.5 times as high (27). We defined nontobacco users as those who reported being currently nonsmokers (or nonsnuff users) with a urinary cotinine concentration below $100 \mathrm{ng} / \mathrm{ml}$.

\section{Respiratory and sensory symptoms}

We used questions (presented in table 2) developed by the International Union Against Tuberculosis and Lung Disease to quantify symptoms; they have been used in similar studies $(1,7,28)$. The participants reported the presence or absence of symptoms in two domains (respiratory and sensory) in the preceding 4 weeks. The same questions were used in the baseline and follow-up examinations.

\section{Measurement of exposure to environmental tobacco smoke}

Nicotine in the air. The nicotine vapor phase was measured using passive samplers for environmental tobacco smoke, which are composed of a 37-mm diameter plastic filter cassette (with a windscreen on one side) that contains a Teflon-coated glass-fiber filter treated with sodium bisulfate $(22,29,30)$. In the subgroup of nonsmokers, the samplers were placed in the breathing zone on the left-hand side of the participants, who wore them during the workday for a period of 2 to 4 days. Among the smokers, the samplers were placed in the workplace for a similar duration rather than being worn so that contamination by the participants' smoking would be avoided. The samplers were placed according to written instructions given to the participants (30). The analysis of the samplers was performed at the Department of Occupational and Environmental Medicine, Örebro University Hospital, Sweden. The limit of detection was $0.0025 \mu \mathrm{g} / \mathrm{sample}$. The nicotine air concentration $\left(\mu \mathrm{g} / \mathrm{m}^{3}\right)$ was obtained by using the sampler uptake rate ( $24 \mathrm{ml} /$ minute) and the time the filter had been exposed; thus the duration of exposure was standardized. The method has previously been fully described, and it has been validated and used in several studies $(22,29-31)$.

We estimated how many participants were over a cut-off level for nicotine in the air relevant to previously defined disease risk. A potent bladder carcinogen, 4-aminobiphenyl (4-ABP), is present in environmental tobacco smoke and has been shown to bond covalently to hemoglobin (22). We chose a cut-off level for nicotine in the air $\left(\geq 0.5 \mu \mathrm{g} / \mathrm{m}^{3}\right)$, previously identified as indicating potentially hazardous levels of 4-ABP (22).

Self-reported exposure. Exposure to environmental tobacco smoke at work, at home, and in other localities over the previous 7 days was recorded in the questionnaire, including information on whether the participants lived with a smoker. Exposure during workhours was 
Table 2. Symptoms of the hospitality workers before and after the ban. $(0 \mathrm{R}=$ odds ratio, $95 \% \mathrm{Cl}=95 \%$ confidence interval, Question 1 : Have you had whistling or wheezing in your chest?, Question 2: Have you felt short of breath?, Question 3: Do you usually cough the first thing in the morning?, Question 4: Do you cough at all during the rest of the day?, Question 5: Do you bring up phlegm?, Question 6: In the past 4 weeks, have your eyes been red or irritated?, Question 7: Have you had a runny nose, sneezing, or nose irritation?, Question 8: Have you had a sore or irritated throat?)

\begin{tabular}{|c|c|c|c|c|c|c|c|c|c|c|c|c|c|c|c|c|c|c|}
\hline & \multicolumn{8}{|c|}{ Preban } & \multicolumn{10}{|c|}{ Postban } \\
\hline & \multicolumn{4}{|c|}{$\begin{array}{l}\text { Total sample at } \\
\text { preban baseline } \\
(\mathrm{N}=91)\end{array}$} & \multicolumn{4}{|c|}{$\begin{array}{l}\text { Preban sample } \\
\text { with postban data } \\
(\mathrm{N}=71 ; 78 \%)\end{array}$} & \multicolumn{4}{|c|}{$\begin{array}{l}\text { Preban sample } \\
\text { with postban data } \\
(\mathrm{N}=71 ; 78 \%)\end{array}$} & \multirow{2}{*}{\multicolumn{2}{|c|}{ All }} & \multirow{2}{*}{\multicolumn{2}{|c|}{ Nonsmokers }} & \multirow{2}{*}{\multicolumn{2}{|c|}{ Smokers }} \\
\hline & \multicolumn{2}{|c|}{$\begin{array}{l}\text { Non- } \\
\text { smok- } \\
\text { ers } \\
(\mathrm{N}=67)\end{array}$} & \multicolumn{2}{|c|}{$\begin{array}{l}\text { Smok- } \\
\text { ers } \\
(\mathrm{N}=24)\end{array}$} & \multicolumn{2}{|c|}{$\begin{array}{l}\text { Non- } \\
\text { smok- } \\
\text { ers } \\
(\mathrm{N}=57)\end{array}$} & \multicolumn{2}{|c|}{$\begin{array}{l}\text { Smok- } \\
\text { ers } \\
(\mathrm{N}=14)\end{array}$} & \multicolumn{2}{|c|}{$\begin{array}{l}\text { Non- } \\
\text { smokers } \\
(\mathrm{N}=57)\end{array}$} & \multicolumn{2}{|c|}{$\begin{array}{l}\text { Smok- } \\
\text { ers } \\
(\mathrm{N}=14)\end{array}$} & & & & & & \\
\hline & $\mathrm{N}$ & $\%$ & $\mathrm{~N}$ & $\%$ & $\mathrm{~N}$ & $\%$ & $\mathrm{~N}$ & $\%$ & $N$ & $\%$ & $\mathrm{~N}$ & $\%$ & $\mathrm{OR}^{\mathrm{a}}$ & $95 \% \mathrm{Cl}$ & $\mathrm{OR}^{\mathrm{a}}$ & $95 \% \mathrm{Cl}$ & $O R^{a}$ & $95 \% \mathrm{Cl}$ \\
\hline $\begin{array}{l}\text { Ques- } \\
\text { tion } 1\end{array}$ & 10 & 14.9 & 9 & 37.5 & 9 & 15.8 & 3 & 21.4 & 6 & 10.5 & 5 & 35.7 & $\begin{array}{l}\text { A } 0.64^{\text {b }} \\
\text { B } 0.85^{\text {b }}\end{array}$ & $\begin{array}{l}\text { A } 0.23-1.80^{b} \\
\text { B } 0.28-2.52^{\text {b }}\end{array}$ & $\begin{array}{l}\text { A } 0.58^{\text {b }} \\
\text { B } 0.56^{\text {b }}\end{array}$ & $\begin{array}{l}\text { A } 0.17-1.97^{\text {b }} \\
\text { B } 0.16-1.91^{\text {b }}\end{array}$ & $\begin{array}{l}\text { A } 26.5^{\text {b }} \\
\text { B } 143^{\text {b }}\end{array}$ & $\begin{array}{l}\text { A } 0.33-2134 \\
B^{c}\end{array}$ \\
\hline $\begin{array}{l}\text { Ques- } \\
\text { tion } 2\end{array}$ & 11 & 16.4 & 4 & 16.7 & 11 & 19.3 & 3 & 21.4 & 6 & 10.5 & 3 & 21.4 & $\begin{array}{l}\text { A } 0.53^{\text {b }} \\
\text { B } 0.44^{\text {b }}\end{array}$ & $\begin{array}{l}\text { A } 0.16-1.71^{b} \\
\text { B } 0.13-1.42^{\text {b }}\end{array}$ & $\begin{array}{l}\text { A } 0.50^{b} \\
\text { B } 0.642^{b}\end{array}$ & $\begin{array}{l}\text { A } 0.13-1.93^{b} \\
\text { B } 0.11-1.63^{\text {b }}\end{array}$ & $\begin{array}{l}\text { A } 0.66^{b} \\
\text { B } 0.52^{\text {b }}\end{array}$ & $\begin{array}{l}\text { A } 0.06-6.83^{b} \\
\text { В } 0.05-5.67^{\text {b }}\end{array}$ \\
\hline $\begin{array}{l}\text { Ques- } \\
\text { tion } 3\end{array}$ & 25 & 37.3 & 9 & 37.5 & 23 & 40.4 & 3 & 21.4 & 9 & 15.8 & 6 & 42.9 & $\begin{array}{l}\text { A } 0.44^{b, d} \\
\text { B } 0.46^{b}\end{array}$ & $\begin{array}{l}\text { A } 0.14-0.90^{b, d} \\
\text { B } 0.22-0.97^{b}\end{array}$ & $\begin{array}{l}\text { A } 0.36^{b, d} \\
\text { B } 0.33^{b}\end{array}$ & $\begin{array}{l}\text { A } 0.14-0.87^{b, d} \\
\text { B } 0.13-0.81^{b}\end{array}$ & $\begin{array}{l}\text { A } 0.72^{b} \\
\text { B } 1.02^{b}\end{array}$ & $\begin{array}{l}\text { A } 0.20-2.60^{b} \\
\text { B } 0.24-4.19^{b}\end{array}$ \\
\hline $\begin{array}{l}\text { Ques- } \\
\text { tion } 4\end{array}$ & 33 & 46.3 & 14 & 58.3 & 31 & 54.4 & 8 & 57.1 & 12 & 21.1 & 6 & 42.9 & $\begin{array}{l}\text { A } 0.28^{b} \\
\text { B } 0.25^{b}\end{array}$ & $\begin{array}{l}\text { A } 0.12-0.62^{\mathrm{b}} \\
\text { B } 0.11-0.56^{\text {b }}\end{array}$ & $\begin{array}{l}\text { A } 0.22^{b} \\
\text { B } 0.19^{b}\end{array}$ & $\begin{array}{l}\text { A } 0.08-0.63^{\text {b }} \\
\text { B } 0.06-0.55^{\text {b }}\end{array}$ & $\begin{array}{l}\text { A } 0.40^{\mathrm{b}} \\
\text { B } 0.37^{\mathrm{b}}\end{array}$ & $\begin{array}{l}\text { A } 0.11-1.44^{b} \\
\text { B } 0.09-1.54^{b}\end{array}$ \\
\hline $\begin{array}{l}\text { Ques- } \\
\text { tion } 5\end{array}$ & 22 & 32.8 & 8 & 33.3 & 20 & 35.1 & 3 & 21.4 & 12 & 21.1 & 5 & 35.7 & $\begin{array}{l}\text { A } 0.36^{\mathrm{b}} \\
\text { B } 0.38^{\mathrm{b}}\end{array}$ & $\begin{array}{l}\text { A } 0.12-1.13^{b} \\
\text { B } 0.12-1.22^{b}\end{array}$ & $\begin{array}{l}\mathrm{A} 0.22^{\mathrm{b}} \\
\mathrm{B} 0.21^{\mathrm{b}}\end{array}$ & $\begin{array}{l}\text { A } 0.05-1.01^{\text {b }} \\
\text { B } 0.04-0.96^{\text {b }}\end{array}$ & $\begin{array}{l}\text { A } 1.51^{\mathrm{b}} \\
\text { B } 2.03^{\mathrm{b}}\end{array}$ & $\begin{array}{l}\text { A } 0.14-16.0^{b} \\
\text { B } 0.18-22.7^{b}\end{array}$ \\
\hline $\begin{array}{l}\text { Ques- } \\
\text { tion } 6\end{array}$ & 34 & 50.7 & 9 & 37.5 & 29 & 50.9 & 5 & 35.7 & 9 & 15.8 & 2 & 14.3 & $\begin{array}{l}\text { A } 0.12^{\mathrm{b}} \\
\mathrm{B} 0.11^{\mathrm{b}}\end{array}$ & $\begin{array}{l}\text { A } 0.04-0.38^{b} \\
\text { B } 0.03-0.38^{b}\end{array}$ & $\begin{array}{l}\text { A } 0.09^{b} \\
\text { B } 0.09^{b}\end{array}$ & $\begin{array}{l}\text { A } 0.02-0.39^{b} \\
\text { B } 0.02-0.40^{\text {b }}\end{array}$ & $\begin{array}{l}\text { A } 0.24^{\mathrm{b}} \\
\text { B } 0.21^{\mathrm{b}}\end{array}$ & $\begin{array}{l}\text { A } 0.03-1.86^{b} \\
\text { B } 0.02-1.75^{b}\end{array}$ \\
\hline $\begin{array}{l}\text { Ques- } \\
\text { tion } 7\end{array}$ & 44 & 65.7 & 14 & 58.3 & 39 & 68.4 & 9 & 64.3 & 21 & 36.8 & 9 & 64.3 & $\begin{array}{l}\text { A } 0.37^{\text {b }} \\
\text { B } 0.31^{\text {b }}\end{array}$ & $\begin{array}{l}\text { A } 0.18-0.79^{b} \\
\text { B } 0.14-0.69^{b}\end{array}$ & $\begin{array}{l}\text { A } 0.32^{\mathrm{b}} \\
\text { B } 0.28^{\mathrm{b}}\end{array}$ & $\begin{array}{l}\text { A } 0.13-0.76^{b} \\
\text { B } 0.11-0.68^{b}\end{array}$ & $\begin{array}{l}\text { A } 0.70^{\mathrm{b}} \\
\text { B } 0.50^{\mathrm{b}}\end{array}$ & $\begin{array}{l}\text { A } 0.15-3.21^{b} \\
\text { B } 0.09-2.73^{b}\end{array}$ \\
\hline $\begin{array}{l}\text { Ques- } \\
\text { tion } 8\end{array}$ & 37 & 55.2 & 7 & 29.2 & 32 & 56.1 & 3 & 21.4 & 12 & 21.1 & 7 & 50.0 & $\begin{array}{l}\text { A } 0.36^{\mathrm{b}} \\
\text { B } 0.35^{\mathrm{b}}\end{array}$ & $\begin{array}{l}\text { A } 0.17-0.75^{b} \\
\text { В } 0.16-0.76^{b}\end{array}$ & $\begin{array}{l}\text { A } 0.18^{b} \\
B 0.18^{b}\end{array}$ & $\begin{array}{l}\text { A } 0.06-0.51^{\text {b }} \\
\text { B } 0.06-0.52^{\text {b }}\end{array}$ & $\begin{array}{l}\text { A } 1.31^{\mathrm{b}} \\
\text { B } 1.66^{\mathrm{b}}\end{array}$ & $\begin{array}{l}\text { A } 0.37-4.68^{b} \\
\text { B } 0.39-7.04^{\text {b }}\end{array}$ \\
\hline
\end{tabular}

a OR for symptoms when comparing postban to preban period.

${ }^{\mathrm{b}} \mathrm{A}$ includes panel data on all of those who participated in the preban examination, while B is restricted to those who participated in both the pre- and postban examinations.

c Not presented due to low precision (not statistically significant).

d The XT-logit model did not converge; hence an estimate could not be made. Therefore, we provided an estimate using logistic regression.

recorded in a diary for three consecutive days during both periods.

\section{Attitudes towards the legislation on environmental tobacco smoke}

At both examinations, the participants reported their attitude towards the legislation on environmental tobacco smoke using a scale from 0 to 100 , on which a higher score indicated a more positive response. In our analyses, we dichotomized the score at 75 to define general satisfaction with the legislation. The question was "What is your opinion of the tobacco smoking legislation?", with requested comments on the participant him- or herself, hospitality workers in general, the employer, and the clients.

\section{Spirometry}

All of the participants underwent a spirometric examination; they were assessed in one of the nine recognized pulmonary function clinics used by the study. All of the clinics followed written instructions from the study coordinator, which were based on guidelines of the European Respiratory Society (32), and it included instructions about calibration and measurements of forced expiratory volume in 1 second (FEV1) and forced vital capacity (FVC). The same spirometer was used pre- and postban for all of the participants. The FEV1 value, as well as the FVC, was recorded before and 15 minutes after the inhalation of $0.4 \mathrm{mg}$ of salbutamol (or $0.8 \mathrm{mg}$ of terbutalin). The highest FEV1 and FVC values from at least three attempts were recorded.

\section{Statistical analysis}

We examined the characteristics of the participants using cross-tabulation, and statistical significance was assessed by the chi-square test. The test for trend was used to estimate changes in tobacco consumption. All of the analyses were performed for the total sample, as well as 
for two subgroups based on occupation. Gaming workers were employed in bingo halls $(\mathrm{N}=22)$ and casinos $(\mathrm{N}=15)$, while the remainder of the hospitality workers have been identified as "other workers" $(\mathrm{N}=54)$.

To measure the change in respiratory and sensory symptoms between the data collections, we used the XT-logit procedure provided by Stata software (Stata Corporation, College Station, TX, USA). This is a form of logistic regression specifically developed for panel data for which there is an explicit time component. When workers participate at both time points, this technique links the data and estimates individual change. It can also use estimates from those who participate only once. Data from the 91 participants who were included at baseline could be used in the analyses comparing the population at the two time points. We also limited the analysis to the 71 persons who participated in both examinations to ensure the results were not influenced by attrition-associated bias. The XT-logit models were adjusted for age, gender, and smoking. The analysis was also stratified by smoking behavior.

To estimate the reduction in the exposure to environmental tobacco smoke after the introduction of legislation, we used logistic regression to estimate how many participants were exposed above the cut-off value of $<0.5 \mu \mathrm{g} / \mathrm{m}^{3}$ of nicotine in the air. A similar analysis examined the dichotomized attitude scores. When it was not possible to report odds ratios, with $95 \%$ confidence intervals $(95 \% \mathrm{CI})$ due to empty cells, relative risks were reported in their place.

Pulmonary function tests were recorded preban and postban and analyzed for each parameter (FEV1 and FVC). We compared the predicted score for the pre- and postban periods using the paired-sample t-test procedure. We also used potentially more sensitive analyses to identify differences in lung function between the time points. To assess differences in reversible bronchial reactivity during the study period, delta-FEV1 was calculated for the difference in capacity before and after a beta- 2 agonist was administered. Linear regression was used to assess the differences in this measure, with adjustment for gender, age, and height. A similar analysis was conducted for FEV1. Smokers were excluded from these analyses.

The analysis was conducted using SPSS (SPSS Inc, Chicago, IL, USA) and Stata software.

\section{Results}

\section{Hospitality workers' characteristics}

Table 1 summarizes the characteristics of the participants. A total of 91 persons volunteered and fulfilled the inclusion criteria. Women predominated, and there were relatively few smokers. Persons lost to follow-up were somewhat younger and were more likely to be smokers, but they did not differ from the overall group by gender, and (preban) attitudes towards the legislation.

\section{Tobacco habits}

Table 1 shows that most of the participants were nonsmokers. One smoker, as well as one nonsmoker, used moist snuff regularly at the follow-up. No one changed their smoking status, and the average daily consumption among the smokers decreased slightly from a median of 17 to 15 cigarettes/day, but this reduction was not statistically significant ( $\mathrm{P}$ for trend $=0.788$ ).

Preban, the number of smokers among the gaming workers was 11 of $37(30 \%)$, and postban the number was 6 of 27 (22\%); among the other workers, 13 of 54 (24\%) and 8 of 44 (18\%) preban and postban, respectively, were smokers. There was no statistically significant decline in the number of cigarettes smoked per day when the two occupational groups were examined separately.

\section{Screening of unreported smoking or snuff use accord- ing to urinary cotinine level}

We were able to analyze urinary cotinine for $79 \%$ of the participants in both the preban and postban periods. Storage and transportation problems were the main reasons that we were unable to analyze all of the urine samples. Three persons who reported no tobacco use had urinary cotinine values exceeding the cut-off level of $100 \mathrm{ng} / \mathrm{ml}$ [one at baseline $(195 \mathrm{ng} / \mathrm{ml})$ and two others at follow-up $(283 \mathrm{ng} / \mathrm{ml})]$. All three were included in the analyses but were reclassified as smokers. Before the ban, urinary cotinine was under the detection limit for 16 of $43(37 \%)$ nontobacco users, while, after the ban, it was below this limit in 29 of 43 (67\%) of those who did not use tobacco.

\section{Respiratory and sensory symptoms}

Table 2 shows the prevalence of respiratory and sensory symptoms among the smokers and nonsmokers before and 12 months after the introduction of the ban. In the entire study population, all of the reported symptoms declined, and the decline was statistically significant for questions about cough in the morning, cough during the rest of the day, eye irritation, nose irritation, and throat symptoms. Using data for all of the nonsmokers $(\mathrm{N}=67)$ participating in the preban sweep gave approximately the same results as the analyses using only those who completed the questionnaire both in the preban and postban examination $(\mathrm{N}=54)$. Among the smokers, there was no notable association between symptoms and period, 
but the small number of smokers makes this result difficult to interpret.

Table 3 shows the prevalence of the respiratory and sensory symptoms presented in table 2 divided into gaming workers and other workers. Among the gaming workers, the odds ratio declined more for cough in the morning, cough the rest of the day, and bringing up phlegm, while the remaining five symptoms declined somewhat more among the other workers. None of the difference between these groups was statistically significant.

\section{Exposure to environmental tobacco smoke}

Nicotine in the air. There was a reduction in the median level of nicotine measured in the air between the baseline and the 12-month follow-up from $7.50 \mu \mathrm{g} / \mathrm{m}^{3}$ to $0.16 \mu \mathrm{g} / \mathrm{m}^{3}\left(12.6-0.2 \mu \mathrm{g} / \mathrm{m}^{3}\right.$ among the smokers and $6.2-0.2 \mu \mathrm{g} / \mathrm{m}^{3}$ among the nonsmokers). When quantified in terms of risk reduction, before the ban, $87 \%$ of the participants had exposure to environmental tobacco smoke over the nicotine cut-off level of $<0.5 \mu \mathrm{g} / \mathrm{m}^{3}$, while, after the ban, it was only $22 \%$, representing a reduced relative risk of $0.25(95 \% \mathrm{CI} 0.15-0.41)$ in the total sample. Nicotine in the air, before the ban, was under the detection limit in 1 of $54(2 \%)$ of the nontobacco users, while, after the ban, it was under the limit in 17 of $54(31 \%)$ of the nontobacco users.

Preban (all observations included), the number of gaming workers with exposure over the cut-off nicotine level of $<0.5 \mu \mathrm{g} / \mathrm{m}^{3}$ was 36 of $36(100 \%)$ persons, while, among the other workers, the proportion was 38 of 47 (81\%) persons, corresponding to a relative risk of 1.24 (95\% CI 1.08-1.42).

Table 3. Symptoms among the gaming and other workers before and after the ban.

\begin{tabular}{|c|c|c|c|c|c|c|c|c|}
\hline \multirow[t]{3}{*}{ Group } & \multicolumn{4}{|c|}{ Preban } & \multicolumn{4}{|c|}{ Postban } \\
\hline & \multicolumn{2}{|c|}{$\begin{array}{l}\text { Total sample } \\
\text { at the preban } \\
\text { baseline }\end{array}$} & \multicolumn{2}{|c|}{$\begin{array}{c}\text { Preban } \\
\text { sample with } \\
\text { postban data }\end{array}$} & \multicolumn{2}{|c|}{$\begin{array}{l}\text { Preban sample } \\
\text { with postban } \\
\text { data }\end{array}$} & \multirow[b]{2}{*}{$\mathrm{OR}$} & \multirow[b]{2}{*}{$95 \% \mathrm{Cl}$} \\
\hline & N & $\%$ & N & $\%$ & $\mathrm{~N}$ & $\%$ & & \\
\hline Gaming workers & 37 & 100 & 27 & 100 & 27 & 100 & & \\
\hline Question 1: Have you had whistling or wheezing in your chest? & 9 & 24.3 & 6 & 22.2 & 6 & 22.2 & $\begin{array}{l}\text { A } 0.97^{\mathrm{a}} \\
\text { B } 0.98^{\mathrm{a}}\end{array}$ & $\begin{array}{l}0.21-4.54^{\mathrm{a}} \\
0.20-4.81^{\mathrm{a}}\end{array}$ \\
\hline Question 2: Have you felt short of breath? & 9 & 24.3 & 8 & 29.6 & 6 & 22.2 & $\begin{array}{l}\text { A } 0.64^{a} \\
\text { B } 0.49^{a}\end{array}$ & $\begin{array}{l}0.12-3.42^{\mathrm{a}} \\
0.09-2.69^{\mathrm{a}}\end{array}$ \\
\hline Question 3: Do you usually cough the first thing in the morning? & 15 & 40.5 & 13 & 48.1 & 5 & 18.5 & $\begin{array}{l}\text { A } 0.34^{\text {a }} \\
\text { B } 0.23^{\text {a }}\end{array}$ & $\begin{array}{l}0.10-1.10^{a} \\
0.06-0.81^{a}\end{array}$ \\
\hline Question 4: Do you cough at all during the rest of the day? & 20 & 54.1 & 18 & 66.7 & 9 & 33.3 & $\begin{array}{l}\text { A } 0.18^{a} \\
\text { B } 0.10^{a}\end{array}$ & $\begin{array}{l}0.02-1.33^{\mathrm{a}} \\
0.01-0.78^{\mathrm{a}}\end{array}$ \\
\hline Question 5: Do you bring up phlegm? & 14 & 37.8 & 12 & 44.4 & 8 & 29.6 & $\begin{array}{l}\text { A } 0.26^{\mathrm{a}} \\
\text { B } 0.19^{\mathrm{a}}\end{array}$ & $\begin{array}{l}0.03-2.14^{\mathrm{a}} \\
0.02-1.61^{\mathrm{a}}\end{array}$ \\
\hline Question 6: In the past 4 weeks, have your eyes been red or irritated? & 15 & 40.5 & 10 & 37.0 & 4 & 14.8 & $\begin{array}{l}\text { A } 0.21^{\text {a }} \\
\text { B } 0.26^{\text {a }}\end{array}$ & $\begin{array}{l}0.05-0.95^{a} \\
0.05-1.19^{a}\end{array}$ \\
\hline Question 7: Have you had a runny nose, sneezing, or nose irritation? & 23 & 62.2 & 19 & 70.4 & 14 & 51.9 & $\begin{array}{l}\text { A } 0.62^{\mathrm{a}} \\
\text { B } 0.39^{\mathrm{a}}\end{array}$ & $\begin{array}{l}0.18-2.09^{a} \\
0.10-1.45^{a}\end{array}$ \\
\hline Question 8: Have you had a sore or irritated throat? & 20 & 54.1 & 14 & 51.9 & 9 & 33.3 & $\begin{array}{l}\text { A } 0.41^{\mathrm{a}} \\
\text { B } 0.43^{\mathrm{a}}\end{array}$ & $\begin{array}{l}0.14-1.18^{\mathrm{a}} \\
0.14-1.35^{\mathrm{a}}\end{array}$ \\
\hline Other workers & 54 & 100 & 44 & 100 & 44 & 100 & & \\
\hline Question 1: Have you had whistling or wheezing in your chest? & 10 & 18.5 & 6 & 13.6 & 5 & 11.4 & $\begin{array}{l}\text { A } 0.58^{a} \\
\text { B } 0.76^{a}\end{array}$ & $\begin{array}{l}0.14-2.42^{a} \\
0.17-3.38^{a}\end{array}$ \\
\hline Question 2: Have you felt short of breath? & 6 & 11.1 & 6 & 13.6 & 3 & 6.8 & $\begin{array}{l}\text { A } 0.49^{a} \\
\text { B } 0.40^{a}\end{array}$ & $\begin{array}{l}0.09-2.58^{a} \\
0.08-2.06^{a}\end{array}$ \\
\hline Question 3: Do you usually cough the first thing in the morning? & 19 & 35.2 & 13 & 29.5 & 10 & 22.7 & $\begin{array}{l}\text { A } 0.56^{\mathrm{a}} \\
\text { B } 0.70^{\mathrm{a}}\end{array}$ & $\begin{array}{l}0.22-1.39^{\mathrm{a}} \\
0.27-1.82^{\mathrm{a}}\end{array}$ \\
\hline Question 4: Do you cough at all during the rest of the day? & 27 & 50.0 & 21 & 47.7 & 9 & 20.5 & $\begin{array}{l}\text { A } 0.24^{\text {a }} \\
\text { B } 0.26^{\text {a }}\end{array}$ & $\begin{array}{l}0.09-0.62^{\mathrm{a}} \\
0.10-0.70^{\mathrm{a}}\end{array}$ \\
\hline Question 5: Do you bring up phlegm? & 16 & 29.6 & 11 & 25.0 & 9 & 20.5 & $\begin{array}{l}\text { A } 0.45^{\mathrm{a}} \\
\text { B } 0.56^{\mathrm{a}}\end{array}$ & $\begin{array}{l}0.11-1.84^{\mathrm{a}} \\
0.13-2.39^{\mathrm{a}}\end{array}$ \\
\hline Question 6: In the past 4 weeks, have your eyes been red or irritated? & 28 & 51.9 & 24 & 54.5 & 7 & 15.9 & $\begin{array}{l}\text { A } 0.05^{\mathrm{a}} \\
\text { B } 0.05^{\mathrm{a}}\end{array}$ & $\begin{array}{l}0.01-0.41^{a} \\
0.01-0.40^{a}\end{array}$ \\
\hline Question 7: Have you had a runny nose, sneezing, or nose irritation? & 35 & 64.8 & 29 & 65.9 & 16 & 36.4 & $\begin{array}{l}\text { A } 0.28^{a} \\
\text { B } 0.28^{a}\end{array}$ & $\begin{array}{l}0.11-0.75^{\mathrm{a}} \\
0.10-0.74^{\mathrm{a}}\end{array}$ \\
\hline Question 8: Have you had a sore or irritated throat? & 24 & 44.4 & 21 & 47.7 & 10 & 22.7 & $\begin{array}{l}\text { A } 0.27^{\text {a }} \\
\text { B } 0.26^{\text {a }}\end{array}$ & $\begin{array}{l}0.09-0.81^{\mathrm{a}} \\
0.08-0.79 \mathrm{a}\end{array}$ \\
\hline
\end{tabular}

a For symptoms when the postban period is compared with the preban period (A includes panel data of all those participating in the preban examination, while $B$ is restricted to those who participated in both the pre- and postban examinations). 
There was a reduction in the median nicotine level measured in the air between the baseline and 12-month follow-up among the gaming workers from $11.0 \mu \mathrm{g} / \mathrm{m}^{3}$ to $0.22 \mu \mathrm{g} / \mathrm{m}^{3}$ and among other workers from $2.95 \mu \mathrm{g} / \mathrm{m}^{3}$ to $0.12 \mu \mathrm{g} / \mathrm{m}^{3}$. Among the gaming workers, $100 \%$ were exposed over the cut-off value before the legislation, but only $22 \%$ were so exposed at the follow up. This difference can be estimated as a relative risk of $0.25(95 \% \mathrm{CI}$ $0.15-0.41$ ), P-value $<0.001$ (odds ratio not calculated due to an empty cell). Among the other workers, $78 \%$ of the participants were over the cut-off level before the ban, while $23 \%$ were over the ban at the follow-up, giving a relative risk of 0.29 (95\%CI 0.15-0.55), P-value $<0.001$.

Self-reported exposure. Before the ban, 59 of 91 (65\%) persons reported exposure to environmental tobacco smoke for $75 \%$ or more of their worktime, while at the follow-up such exposure was the case for only 1 of 71 $(1 \%)$ persons, $\mathrm{P}<0.001)$. The duration of exposure to environmental tobacco smoke at home was unchanged (data not shown).

In other localities (not at work or at home), 35 of 71 (49\%) participants reported exposure to environmental tobacco smoke in excess of 1 hour, while, after the ban, it was 7 of $71(10 \%)$ persons, $\mathrm{P}<0.001$.

Preban, there was longer exposure to environmental tobacco smoke at work among the gaming workers than among the others, P-value for trend 0.029. The duration of postban exposure to environmental tobacco smoke was similar in both groups (data not shown).

Attitudes towards the legislation on environmental tobacco smoke. Table 4 indicates that the number of participants reporting that they thought that both employers and clients were satisfied with the legislation (a score of 75 or over) showed a statistically significant increase over the pre- and postban periods.

The gaming and other workers' attitudes on how the employer would be affected by the legislation differed before the ban. The proportion satisfied was 19 of 37 (51\%) among the gaming workers and 39 of $51(76 \%)$ among the other workers (OR 3.1, 95\% CI 1.2-7.7, $\mathrm{P}=0.014)$. This difference was independent of age and gender, as indicated by the multivariate logistic regression analysis. After the ban, this difference was reduced. Some $89 \%$ of the gaming workers, compared with $93 \%$ of other workers, were satisfied in this respect $(\mathrm{P}=0.528)$.

Spirometry. The mean FEV1 for the nonsmokers (percentage of the expected value) was defined as $100 \%$ at the baseline, and, after 12 months, it had declined slightly to $99 \%$. Among the smokers, it fell from $93 \%$ to $90 \%$. The mean FVC of the nonsmokers was $93 \%$ at the baseline and $92 \%$ after 12 months, and, among the smokers, it fell from $94 \%$ to $92 \%$.

The delta-FEV1 did not change notably or statistically significantly over the study period. The regression analysis produced adjusted coefficients of 0.020 (95\%CI $-0.050-0.090, \mathrm{P}=0.566)$ for the nonsmokers and $-0.004(95 \%$ CI $-0.144-0.137, \mathrm{P}=0.957)$ for the smokers. Similar analyses for FEV1 and FVC did not reveal any notable or statistically significant association with period (data not shown).

\section{Discussion}

\section{Main findings}

The fact that the implementation of the smoke-free legislation was associated with a substantial reduction in respiratory and sensory symptoms among nonsmoking hospitality workers was the main finding of this study. The frequency of reported symptoms was approximately halved among the nonsmokers 1 year after the introduction of the ban. A reduction in symptoms was observed for both the gaming workers (who tended not to have been included in previous studies of exposure to environmental tobacco smoke) and the other hospitality workers. Before the implementation of the legislation, a higher proportion of gaming workers than other hospitality workers was exposed to a potentially hazardous level of exposure to environmental tobacco smoke, but this level was substantially reduced in both occupational groups after the ban; this finding indicates that the legislation was successful in preventing smoking at these workplaces. Although the workers' attitudes towards the legislation were broadly positive before the ban, the proportion that was positive increased during the year following its introduction.

There is evidence that exposure to environmental tobacco smoke represents a health risk $(22,33-37)$. It has

Table 4. Number of "quite satisfied" persons in the total sample of 71 hospitality workers pre- and postban. (NS = not significant)

\begin{tabular}{|c|c|c|c|c|c|}
\hline \multirow{3}{*}{$\begin{array}{l}\text { Attitude towards } \\
\text { the ban }\end{array}$} & \multicolumn{4}{|c|}{ Proportion being "quite satisfied" } & \multirow[t]{3}{*}{ P-value } \\
\hline & \multicolumn{2}{|c|}{ Preban } & \multicolumn{2}{|c|}{ Postban } & \\
\hline & $\begin{array}{l}\text { Propor- } \\
\text { tion }\end{array}$ & $\%$ & $\begin{array}{l}\text { Propor- } \\
\text { tion }\end{array}$ & $\%$ & \\
\hline $\begin{array}{l}\text { Participant's own situation } \\
\text { Hospitality workers' }\end{array}$ & $67 / 71$ & 94.4 & $70 / 71$ & 98.6 & 0.172 (NS) \\
\hline situation in general & $68 / 70$ & 97.1 & $70 / 71$ & 98.6 & 0.552 (NS) \\
\hline Situation of employer & $47 / 69$ & 68.1 & $65 / 71$ & 91.5 & $<0.001$ \\
\hline Situation of clients & $56 / 71$ & 78.9 & $66 / 71$ & 93 & 0.015 \\
\hline
\end{tabular}

${ }^{\mathrm{a}} \chi^{2}$-test. 
been shown that environmental tobacco smoke may be a risk for diseases such as bladder cancer among women who have never used tobacco products $(22,35)$. The cutoff level for nicotine related to environmental tobacco smoke $\left(<0.5 \mu \mathrm{g} / \mathrm{m}^{3}\right)$ was chosen for use in this study because, above this level, the associated 4-ABP exposure may notably increase cancer risk (22). The proportion that was exposed above this level was substantially reduced after implementation of the legislation.

\section{Comparisons with other studies}

There is an increasing number of studies on the effects of smoke-free legislation on hospitality workers; however, many of these studies have been limited to bar workers (1, 7-9, 28). Studies in San Francisco in the United States and in Ireland $(7,9)$ found substantial decreases in self-reported exposure to environmental tobacco smoke at work and also reductions in respiratory and sensory symptoms. The reductions in salivary cotinine concentrations among nonsmoking hospitality workers in New York State (8) were of a similar magnitude as in the Irish study (1), but no notable changes in the frequency of symptoms were found in the former study. Self-reported symptoms decreased in our study by approximately $50 \%$; this level is in accordance with the findings of studies from California and Ireland $(7,9)$.

Our study differed from some previous studies that identified changes in lung function $(1,2,7)$, which we did not detect. This difference may be because the previous studies performed measurements during or shortly after the workshift. Due to the centralized spirometry measurements in our study, that approach was not possible, and approximately $50 \%$ of the spirometry tests were performed either before the workshift or the next day. Therefore, the influence of environmental tobacco smoke on pulmonary function prior to the ban may have been underestimated if there is a close temporal relationship between exposure to environmental tobacco smoke at work and lung function.

Skogstad et al measured lung function before and after shifts (2) and reported a lower cross-shift decrease in some spirometric values postban compared with the preban period. Even when we examined the delta-FEV1 as a potentially more-sensitive measure of the influence of environmental tobacco smoke on lung function, we saw no notable change between the pre- and postban periods.

In contrast with some recent studies (1, 38-40), we found no evidence of a reduction in exposure to environmental tobacco smoke at home, but the number of participants living with a smoker was small. The reduction of reported exposure to environmental tobacco smoke outside home and work may be due to leisure time spent in bars and restaurants that were also smoke-free due to the legislation. In contrast with the study by Braverman et al (41), who reported a significant decline in the prevalence of daily smoking among Norwegian hospitality workers, the slight decrease in the median number of cigarettes smoked by a daily smoker (from 17 to 15/day) in our study was not statistically significant. However, the low number of smokers in our study makes it difficult to draw any firm conclusions.

\section{Limitations of the study}

The voluntary nature of the recruitment process is likely to have resulted in selection bias. We do not have data on the characteristics or number of potential participants, as recruitment was through a form of advertising. Volunteers may have been less likely to smoke and have different attitudes towards smoking and the legislation; therefore the population may not have been entirely representative of the target working population. The loss to follow-up may have further caused a selection of nonsmokers and may also have implications for the representativeness of nonsmokers. A larger decline in symptom prevalence has been shown for workers with a positive attitude (42); therefore, it is possible that selection bias in our study could have had this effect. We were able to assess the urinary level of cotinine for $79 \%$ of the participants, and therefore some of the participants could have been smokers but reported themselves as nonsmokers, thus underestimating the benefits of smokefree legislation as the greatest associations were found for the nonsmokers. Although the attrition of $21 \%$ is not negligible, it is not unexpected, as this form of work is often casual, seasonal, and frequent job changes are common $(1,28)$. Thus the results will be more likely to reflect the characteristics and views of those with a more stable position.

\section{Strengths of the study}

We were able to enroll gaming workers, an occupational area hitherto very scarcely studied in this respect (10). The participants were enrolled from nine different geographic areas in Sweden, from cities with varying population sizes, thus representing a range of climates and living conditions throughout Sweden. The pre- and postban data collection took place among the same persons, employed at the same workplace, and the symptoms were recorded at the same time of year, thereby eliminating seasonal variations and some other possible sources of bias. We used XT-logit analysis, which is specifically designed for longitudinal data when there is an explicit time component so that repeated measures can be examined, even if some participants are lost to follow-up. The participants who were not followed up 
did not differ from the overall group in terms of gender and attitudes towards the ban prior to its introduction, reducing the risk of bias. The reduction of exposure to environmental tobacco smoke was confirmed by an objective measurement-nicotine in the air. In this case, using a specific method for measuring work-related exposure to environmental tobacco smoke meant that only exposure at work was recorded. Previous studies have mainly used indirect assessment methods of exposure to environmental tobacco smoke, including subjective reports (9), particle sampling, or exhaled carbon monoxide (43). The sampling of cotinine from bodily fluids is a more direct measurement of environmental tobacco smoke, and it was also used $(8,9)$. However, urinary cotinine is influenced by individual physiological (respiration, absorption, metabolism, and excretion), temporal (exposure duration), and physical (exposure concentration) parameters (27). Thus factors other than exposure at work (such as leisure-time exposure) could have confounded the urinary cotinine measures. The assessment of exposure to environmental tobacco smoke among smokers or snuff users is not possible with the use of urinary cotinine due to the masking effect of their own tobacco use. Among the nonsmokers, 35\% had preban urinary cotinine values below the detection threshold, and this level may reflect a somewhat lower exposure level than in previous studies $(1,2,9)$, making it difficult to detect a further reduction with this method. However, the very large reduction in nicotine in the air in our study confirms a reduction in the levels of environmental tobacco smoke. By placing air nicotine samplers in different locations for smokers and nonsmokers, we attempted to avoid confounding from the participants' smoking behavior. The nonsmokers wore samplers, but the smokers did not, as smoking during breaks could have masked the true measurement of environmental tobacco smoke for their workplace.

\section{Recommendations for further research}

Our results indicate that gaming workers-previously investigated very little in relation to exposure to environmental tobacco smoke-may have had the most substantial reduction in such exposure, and therefore the effects are worthy of further study.

In our sample, the exposure to environmental tobacco smoke at home remained about the same, while selfreported exposure in other nonwork localities dropped to one-fifth of the preban level; therefore research into the effects of this reduction in exposure is of potential interest.

The benefits and limitations of using portable samplers for nicotine or locality-bound samplers as an alternative to other methods of assessing exposure to environmental tobacco smoke should also be investigated.

\section{Implications for public health}

In conclusion, the legislation on smoke-free workplaces in Sweden has reduced the levels of environmental tobacco smoke for some of the most heavily exposed occupational groups, as indicated by an objective exposure measure. There may also be a notable reduction in exposure outside work when these workers visit bars and restaurants as customers. Implementation of the ban was associated with a reduction in respiratory and sensory symptoms among the nonsmokers. Some of these symptoms, such as cough, are likely to have an impact on the quality of life (44). In the long term, a reduction in hospitality workers' exposure to environmental tobacco smoke may result in other important health effects as such smoke contains carcinogens (22) and is also a recognized cause of atherosclerotic disease (33) and other smoking-related diseases $(34,36,37)$. The health and comfort of hospitality workers may be improved by the smoke-free policy.

\section{Acknowledgments}

We thank Siv Karlsson and Gunnel Löw, RN, from the Tobacco Control Unit, The Department of Respiratory Medicine, Örebro University Hospital, Örebro, Sweden, for coordinating the study, recruiting participants, and collecting data from nine study sites throughout the country. We thank the Occupational and Environmental Health Department at the Stockholm Centre for Public Health, Department of Respiratory Physiology at the Sahlgrenska University Hospital in Göteborg, The Environment Administration in Göteborg, and the pulmonary medicine departments of the Linköping University Hospital, the Malmö University Hospital, Kärnsjukhuset in Skövde, the Uppsala University Hospital, the Västerås Hospital, the Örebro University Hospital, and the Östersund Hospital. We especially thank the hospitality workers who participated in the study. We thank Ing-Liss Bryngelsson, from the Department of Occupational and Environmental Medicine Örebro, University Hospital of Örebro, Sweden, for her help with the data collection, entry, and editing.

A grant was obtained from the Swedish National Institute of Public Health.

\section{References}

1. Allwright S, Paul G, Greiner B, Mullally BJ, Pursell L, Kelly A, et al. Legislation for smoke-free workplaces and health of bar workers in Ireland: before and after study. BMJ. 2005;331(7525): 1117 . 
2. Skogstad M, Kjaerheim K, Fladseth G, Gjolstad M, Daae HL, Olsen R, et al. Cross shift changes in lung function among bar and restaurant workers before and after implementation of a smoking ban. Occup Environ Med. 2006;63(7):482-7.

3. Semple S, Creely KS, Naji A, Miller BG, Ayres JG. Secondhand smoke levels in Scottish pubs: the effect of smoke-free legislation. Tob Control. 2007;16(2):127-32.

4. Howard J. Smoking is an occupational hazard. Am J Ind Med. 2004;46(2):161-9.

5. Siegel M, Barbeau EM, Osinubi OY. The impact of tobacco use and secondhand smoke on hospitality workers. Clin Occup Environ Med. 2006;5(1):31-42, viii.

6. Siegel M, Skeer M. Exposure to secondhand smoke and excess lung cancer mortality risk among workers in the " $5 \mathrm{~B}$ 's": bars, bowling alleys, billiard halls, betting establishments, and bingo parlours. Tob Control. 2003;12(3):333-8.

7. Eisner MD, Smith AK, Blanc PD. Bartenders' respiratory health after establishment of smoke-free bars and taverns. JAMA. 1998;280(22):1909-14.

8. Farrelly MC, Nonnemaker JM, Chou R, Hyland A, Peterson KK, Bauer UE. Changes in hospitality workers' exposure to secondhand smoke following the implementation of New York's smoke-free law. Tob Control. 2005;14(4):236-41.

9. Goodman P, Agnew M, McCaffrey M, Paul G, Clancy L. Effects of the irish smoking ban on respiratory health of bar workers and air quality in dublin pubs. Am J Respir Crit Care Med. 2007;175(8):840-5.

10. Kado NY, McCurdy SA, Tesluk SJ, Hammond SK, Hsieh DP, Jones J, et al. Measuring personal exposure to airborne mutagens and nicotine in environmental tobacco smoke. Mutat Res. 1991;261(1):75-82.

11. Dimich-Ward H, Lawson J, Hingston A, Chan-Yeung M. Impact of smoking policy on the respiratory health of food and beverage servers. Scand J Work Environ Health. 2005;31(1):75-81.

12. Ellingsen DG, Fladseth G, Daae HL, Gjolstad M, Kjaerheim K, Skogstad M, et al. Airborne exposure and biological monitoring of bar and restaurant workers before and after the introduction of a smoking ban. J Environ Monit. 2006;8(3):362-8.

13. Mulcahy M, Evans DS, Hammond SK, Repace JL, Byrne M. Secondhand smoke exposure and risk following the Irish smoking ban: an assessment of salivary cotinine concentrations in hotel workers and air nicotine levels in bars. Tob Control. 2005;14(6):384-8.

14. Steenland K, Thun M, Lally C, Heath C Jr. Environmental tobacco smoke and coronary heart disease in the American Cancer Society CPS-II cohort. Circulation. 1996;94(4):622-8.

15. Kawachi I, Colditz GA, Speizer FE, Manson JE, Stampfer MJ, Willett WC, et al. A prospective study of passive smoking and coronary heart disease. Circulation. 1997;95(10):2374-9.

16. Vineis P, Airoldi L, Veglia F, Olgiati L, Pastorelli R, Autrup $\mathrm{H}$, et al. Environmental tobacco smoke and risk of respiratory cancer and chronic obstructive pulmonary disease in former smokers and never smokers in the EPIC prospective study. BMJ. 2005;330(7486):277.

17. Skorge TD, Eagan TM, Eide GE, Gulsvik A, Bakke PS. The adult incidence of asthma and respiratory symptoms by passive smoking in uterus or in childhood. Am J Respir Crit Care Med. 2005;172(1):61-6.

18. Jaakkola MS, Piipari R, Jaakkola N, Jaakkola JJ. Environmental tobacco smoke and adult-onset asthma: a population-based incident case-control study. Am J Public Health. 2003;93(12):2055-60.

19. Bonita R, Duncan J, Truelsen T, Jackson RT, Beaglehole R.
Passive smoking as well as active smoking increases the risk of acute stroke. Tob Control. 1999;8(2):156-60.

20. Vineis P, Hoek G, Krzyzanowski M, Vigna-Taglianti F, Veglia F, Airoldi L, et al. Lung cancers attributable to environmental tobacco smoke and air pollution in non-smokers in different European countries: a prospective study. Environ Health. 2007;6:7.

21. Zhong L, Goldberg MS, Parent ME, Hanley JA. Exposure to environmental tobacco smoke and the risk of lung cancer: a meta-analysis. Lung Cancer. 2000;27(1):3-18.

22. Hammond SK, Coghlin J, Gann PH, Paul M, Taghizadeh K, Skipper PL, et al. Relationship between environmental tobacco smoke exposure and carcinogen-hemoglobin adduct levels in nonsmokers. J Natl Cancer Inst. 1993;85(6):474-8.

23. James H, Tizabi Y, Taylor R. Rapid method for the simultaneous measurement of nicotine and cotinine in urine and serum by gas chromatography-mass spectrometry. J Chromatogr B Biomed Sci Appl. 1998;708(1-2):87-93.

24. Pirkle JL, Flegal KM, Bernert JT, Brody DJ, Etzel RA, Maurer KR. Exposure of the US population to environmental tobacco smoke: the Third National Health and Nutrition Examination Survey, 1988 to 1991. JAMA. 1996;275(16):1233-40.

25. Jarvis MJ, Foulds J, Feyerabend C. Exposure to passive smoking among bar staff. Br J Addict. 1992;87(1):111-3.

26. Jarvis MJ, Primatesta P, Erens B, Feyerabend C, Bryant A. Measuring nicotine intake in population surveys: comparability of saliva cotinine and plasma cotinine estimates. Nicotine Tob Res. 2003;5(3):349-55.

27. Repace J, Al-Delaimy WK, Bernert JT. Correlating atmospheric and biological markers in studies of secondhand tobacco smoke exposure and dose in children and adults. J Occup Environ Med. 2006;48(2):181-94.

28. Menzies D, Nair A, Williamson PA, Schembri S, Al-Khairalla MZ, Barnes M, et al. Respiratory symptoms, pulmonary function, and markers of inflammation among bar workers before and after a legislative ban on smoking in public places. JAMA. 2006;296(14):1742-8.

29. Hammond SK, Sorensen G, Youngstrom R, Ockene JK. Occupational exposure to environmental tobacco smoke. JAMA. 1995;274(12):956-60.

30. Jane M, Nebot M, Rojano X, Artazcoz L, Sunyer J, Fernandez E, et al. Exposure to environmental tobacco smoke in public places in Barcelona, Spain. Tob Control. 2002;11(1):83-4.

31. Hammond SK. Exposure of US workers to environmental tobacco smoke. Environ Health Perspect. 1999;107 Suppl 2:329-40.

32. Stocks J, Quanjer PH. Reference values for residual volume, functional residual capacity and total lung capacity: ATS workshop on lung volume measurements: Official Statement of The European Respiratory Society. Eur Respir J. 1995;8(3):492506.

33. Barnoya J, Glantz SA. Cardiovascular effects of secondhand smoke: nearly as large as smoking. Circulation. 2005;111(20):2684-98.

34. den Boon S, Verver S, Marais BJ, Enarson DA, Lombard CJ, Bateman ED, et al. Association between passive smoking and infection with Mycobacterium tuberculosis in children. Pediatrics. 2007;119(4):734-9.

35. Jiang X, Yuan JM, Skipper PL, Tannenbaum SR, Yu MC. Environmental tobacco smoke and bladder cancer risk in never smokers of Los Angeles County. Cancer Res. 2007;67(15):7540-5.

36. Trosini-Desert V, Germaud P, Dautzenberg B. Exposition a la fumee du tabac et risque infectieux bacterien [Tobacco smoke 
and risk of bacterial infection]. Rev Mal Respir. 2004;21(3 Pt 1):539-47.

37. Yin P, Jiang CQ, Cheng KK, Lam TH, Lam KH, Miller MR, et al. Passive smoking exposure and risk of COPD among adults in China: the Guangzhou Biobank Cohort Study. Lancet. 2007;370(9589):751-7.

38. Akhtar PC, Currie DB, Currie CE, Haw SJ. Changes in child exposure to environmental tobacco smoke (CHETS) study after implementation of smoke-free legislation in Scotland national cross sectional survey. BMJ. 2007;335(7619):545.

39. Haw SJ, Gruer L. Changes in exposure of adult non-smokers to secondhand smoke after implementation of smoke-free legislation in Scotland: national cross sectional survey. BMJ. 2007;335(7619):549.

40. Phillips R, Amos A, Ritchie D, Cunningham-Burley S, Martin C. Smoking in the home after the smoke-free legislation in Scotland: qualitative study. BMJ. 2007;335(7619):553.

41. Braverman MT, Aaro LE, Hetland J. Changes in smoking among restaurant and bar employees following Norway's comprehensive smoking ban. Health Promot Int. 2008;23(1):515.

42. Eagan TM, Hetland J, Aaro LE. Decline in respiratory symptoms in service workers five months after a public smoking ban. Tob Control. 2006;15(3):242-6.

43. Repace JL, Hyde JN, Brugge D. Air pollution in Boston bars before and after a smoking ban. BMC Public Health. 2006;6:266.

44. Chung K. Review series: chronic cough: future directions in chronic cough: mechanisms and antitussives. Chron Respir Dis. 2007;4(3):159-65.

45. Curbing the epidemic: governments and the economics of tobacco control: The World Bank. Tob Control. 1999;8(2):196201.

Received for publication: 13 December 2007 